\title{
Integration of Improved Methods for the Treatment of Wastewater from a Soft Drink Industry
}

\author{
Décio A. A. Junior ${ }^{1 \mathbb{D}}$, Carolina E. D. Oro ${ }^{1 \mathbb{D}}$, Maicon S. N. dos Santos ${ }^{2 \mathbb{D}}$, Rogério M. Dallago ${ }^{1 \mathbb{D}}$, \\ Marcus V. Tres 2,* (D) \\ 1 Department of Food Engineering, URI Erechim, Brazil; daajunior@bol.com.br (D.A.A.J.); carolinae.oro@ hotmail.com \\ (C.E.D.O.); dallago@uricer.edu.br (R.M.D.); \\ 2 Laboratory of Agroindustrial Processes Engineering (L.A.P.E.), Federal University of Santa Maria, Brazil; \\ maiconsergions@gmail.com (M.S.N.S.); marcus.tres@ufsm.br_(M.V.T.); \\ * Correspondence: marcus.tres@ufsm.br;
}

Scopus Author ID 23096241300

Received: 29.12.2020; Revised: 22.01.2021; Accepted: 24.01.2021; Published: 31.01.2021

\begin{abstract}
Beverage companies produce a large amount of wastewater in the cleaning step of returnable glass bottles. This study aimed to investigate combined processes (coagulation/flocculation, adsorption, and membrane separation) to treat the effluent from the washing machine of returnable soft drink bottles. Tests were conducted with aluminum sulfate, ferric chloride, and tannins (TANFLOC ${ }^{\circledR}$ ) powder as coagulants/flocculants in different concentrations. After choosing the best coagulant, new tests were repeated by adding activated carbon. Based on the coagulant's best condition and activated carbon mass, the treated samples were subjected to a separation step with the ultrafiltration membrane (UF). The best treatment condition was the combined methods (TANFLOC + activated carbon + UF membrane), which showed a removal efficiency of 63.64, 54.92, and 64.98\% for Chemical Oxygen Demand (COD), Total Organic Carbon (TOC), and Biochemical Oxygen Demand (BOD), respectively. The BOD values are due to the presence of sugars in the effluent since its characteristics, such as high polarity and size less than $1 \mathrm{kDa}$, are unfavorable for the coagulation and UF processes, respectively. However, BOD removal efficiency was approximately $5 \%$ higher than the minimum required by legislation, which requires at least a $60 \%$ decrease in the raw effluent.
\end{abstract}

Keywords: activated carbon, biochemical oxygen demand, chemical oxygen demand, TANFLOC, total activated carbon, UF membrane

(C) 2021 by the authors. This article is an open-access article distributed under the terms and conditions of the Creative Commons Attribution (CC BY) license (https://creativecommons.org/licenses/by/4.0/).

\section{Introduction}

In recent years, the non-alcoholic beverage industry has shown a scenario of great expansion, being widely portrayed as one of the largest markets in the world [1]. In 2013, the commercial market in this sector generated approximately 531.3 billion dollars worldwide [2]. In this context, the field of soft drink production is identified as one of the most promising, with production exceeding 465 billion liters and a high potential for advancement [3].

Considering the soft drink industry, specifically, this sector is one of the most important and productive, with a large increase in consumption in recent years [4]. It is estimated that, in 2020, the global revenue from the soft drink trade has already surpassed the mark of 667,384 million dollars, with growth forecasts of $6.5 \%$ in the next five years [5]. Also, in countries with a large population, such as Brazil, the per capita consumption of soft drinks $(74.5 \mathrm{~L} / \mathrm{hab})$ is considerably higher than that of other non-alcoholic beverages, such as water $(39.5 \mathrm{~L} / \mathrm{hab})$, and 
juices (0.6-0.8 L/hab) [6]. However, this promising scenario has shown serious adversities, mainly related to the inappropriate use of resources for the production and manufacturing processes. Several studies have recently directed attention to alternative strategies adopted to obtain a final product exclusively focused on human health and reduce harmful compounds [711]. Some studies have shown interest in treating residues from soft drink industries and applying an environmentally friendly approach [12-14]. However, there has been a large gap in knowledge about sustainable processes involving post-production and commercialization dynamics and the elements necessary for the production dynamics performance.

It is estimated that, for the production of $1 \mathrm{~L}$ of soft drink, $2 \mathrm{~L}$ of water are needed, which shows the large consumption of this element destined for the large production of billions of liters of soft drinks annually worldwide [15]. The use of large amounts of water for this process results in an accentuated flow of waste and liquid effluents in the environment, potentially reusable [16]. Among the main contributors to this scenario, most technical factors are highlighted, such as cleaning machines and equipment and washing bottles for reuse [17].

Several factors influence the efficiency of the hygiene and reuse stages of soft drink packaging. The use of energy for the regulation of the washing temperature, the application of chemicals as aseptic methods, and the use of large amounts of water to satisfy the high pressures required for cleaning jets are fundamental components to meet the specificities required for the washing and cleaning process of these products [18]. However, high costs, space requirements, and highly qualified and technical labor are serious setbacks the soft drinks beverage industries face for correct wastewater treatment for reuse [19].

The wastewater from these industries has high concentrations of biodegradable organic and inorganic substances, as well as wastes and remains of soft drinks, water from washing bottles, cans, and machinery, chemicals used for cleaning and washing, and remnants of lubricating materials used to maintain the functioning of production machines [20]. Thus, it is evident the necessity for alternative methods that consider the reuse and treatment of basic resources, such as water, to reuse industrial procedures and applications to maximize the economic and sustainable advantages.

The conventional methods based on chemical substances and their effects in treating wastewater from various industrial fields are widely investigated, mainly due to its physicochemical properties and adsorptive potential. Chemical elements such as aluminum sulfate, ferric chloride, and activated carbon showed outstanding performance in the treatment process, mainly due to the physicochemical characteristics, adsorption mechanism, and high commercial availability [21-23]. However, these methods have some disadvantages, especially according to the economic point of view and the degradation process [24]. In this context, applying alternative strategies that minimize these adversities has been explored in recent years. A good example is the application of tannin from plant species as a flocculating agent (Tanfloc). Industrially, this technology has been investigated due to its successful application for several purposes and a biodegradable product and advantageous from a sustainable perspective [24]. However, the use of membranes has shown great potential and advantages for treating wastewater in recent years.

The wastewater recovery process through the use of membranes has been reported with highly promising perspectives. With the possibility of using more compact equipment, reduced energy demand, and low costs, this strategy has been adopted in the beverage and food-related industries [25]. The expansion according to the use of these technologies results from adapting the product to the markets and industries' demands, aiming at benefits in operational processes 
[26]. Some studies related to the beverage industries have shown that membrane treatment processes, mainly microfiltration (MF), ultrafiltration (UF), nanofiltration (NF), reverse osmosis (RO), and in processes involving activated sludge to remove organic pollutants, presented satisfactory results in removing microorganisms and unwanted substances [27]. Thus, this method for obtaining and reusing purified water and reusable elements was pointed out as an excellent alternative to treating water in these industries. It presents high prospects for further studies of exploiting this technology in beverage and food-related industries.

In this context, this study investigates the combined processes (physicochemical and membrane separation processes) to treat wastewater from soft drinks industries, resulting from the washing processes of glass bottles. The returnable glasswasher's monthly water consumption in the present study is around $8,300 \mathrm{~m}^{3}$, which justifies the treatment of this effluent and the reuse of treated water in other industrial processes.

\section{Materials and Methods}

\subsection{Effluent.}

The effluent used in the present study was collected from a glass bottle washer of a soft drink company located in the Rio Grande do Sul (Brazil). As the glass bottle is reusable, this cleaning must have maximum efficiency in removing contaminating materials and dirt that may be present inside and outside the bottles. 200 liters of effluents were collected and stored in 25-liter drums. Subsequently, the effluent was frozen to maintain its original qualities during the analysis.

\subsection{Experimental apparatus.}

A hollow fiber type ultrafiltration polymeric membrane (UF) supplied by the company PAM Membranas Seletivas Ltda., composed of a mixture of poly (sulfone ether)/poly (vinyl pyrrolidone) (PES/PVP), with a cut of $50 \mathrm{kDa}$ and a permeation area of $0.027 \mathrm{~m}^{2}$, was used.

The hydraulic system assembled to carry out the experiments consisted of flexible PVC (polyvinyl chloride) hoses with a "1/4" nominal diameter. To control the temperature, a thermostatic bath (model MA 083, Marconi) was used with an accuracy of $\pm 0.1^{\circ} \mathrm{C}$. In the filtration system with the UF membrane, a gear pump (model Micropump 72211-15, ColeParmer) was used. The pressure control was performed through a needle valve (model SS, Nupro Co.) in the line of the retained, posterior to a pressure gauge (Standart, Salvi model). The flux was monitored using a frequency inverter coupled to the pump. The system also had a rotameter (model 440, Conaut).

The raw effluent was filtered on filter paper before proceeding to the membrane process. With the assay using the UF membrane $\left(25^{\circ} \mathrm{C}, 1 \mathrm{bar}\right.$, and flow rate of $\left.1 \mathrm{~L} \cdot \mathrm{min}^{-1}\right)$, the first $50 \mathrm{~mL}$ of permeate was discarded to guarantee the sample's uniformity. Then, the sample's permeate flux was measured every 10 minutes, recomposing both the permeate and the retained one to maintain its homogeneity. After measuring the permeate flux for 60 minutes, a $14 \mathrm{~mL}$ aliquot of permeate was removed. The respective retained one was removed from the system to avoid concentration in the feed. This sample volume represents the quantity needed for analytical determinations.

The permeate and retained aliquots were stored refrigerated at $4{ }^{\circ} \mathrm{C}$ for approximately 18 hours until the analytical determinations were performed. The same procedure was performed for all treated effluent samples. 


\subsection{Membrane cleaning.}

The cleaning protocol adopted for the UF membrane followed the following steps: washing with $5 \mathrm{~L}$ of distilled water, removing water from the system, and immersing the membrane in a commercial descaling solution $\left(5 \mathrm{~g} . \mathrm{L}^{-1}\right)$ for 3 hours. The commercial solution used was composed of sodium percarbonate $(<55 \%)$, sodium carbonate $(<45 \%)$, ethoxylated alcohol $(<3 \%)$, sodium alkyl sulfonate $(<3 \%)$, tetra acetyl ethylene diamine with carboxyethyl cellulose of sodium $(<0.6 \%)$, sodium xylene sulfonate $(0.5 \%)$, linear sodium dodecylbenzene sulfonate $80 \%(<3 \%)$, alpha-amylase enzyme $(<0.2 \%)$, protease enzyme $(<0.3 \%)$, inert ingredients (100\% qsp). Afterward, cleaning was performed with distilled water, first washing the membrane with $5 \mathrm{~L}$ of distilled water without pressurizing the system and another $2 \mathrm{~L}$ under the pressure of 3 bar. During all cleaning, it was kept at room temperature $\left(25^{\circ} \mathrm{C}\right)$.

After each membrane cleaning process, hydraulic permeability with distilled water was rechecked. If a permeability close to that obtained before the experiment was not reached, the cleaning step was repeated until reaching the level before filtration with the sample.

\subsection{Physico-chemical process by coagulation/flocculation and adsorption with activated} carbon.

Tests were carried out with aluminum sulfate (10\% solution), ferric chloride (1\% solution), and tannins $\left(\right.$ TANFLOC $^{\circledR}$ ) powder as coagulants/flocculants. Firstly, tests were carried out with aluminum sulfate $\mathrm{Al}_{2}\left(\mathrm{SO}_{4}\right)_{3}$, with concentrations of 2.0 to $5.0 \mathrm{~mL} . \mathrm{L}^{-1}$. For ferric chloride $\left(\mathrm{FeCl}_{3}\right)$ and TANFLOC, concentrations between 10 to 50 and 30 and $80 \mathrm{mg}$. $\mathrm{L}^{-1}$ were tested. For aluminum sulfate and ferric chloride, the $\mathrm{pH}$ was previously adjusted to $6.0 \pm$ 0.5 , with a $0.1 \mathrm{M} \mathrm{NaOH}$ solution. For TANFLOC, the $\mathrm{pH}$ was previously adjusted to $8.0 \pm 0.5$ with $0.1 \mathrm{M} \mathrm{NaOH}$ solution.

After a homogenization step for all tests using a coagulant, the solution was left to stand for 25 minutes for decanting to occur. Subsequently, the liquid phase was filtered on filter paper and analyzed for COD and TOC values to determine the best coagulant concentration to be used.

After choosing the best coagulant for the effluent, new tests were repeated with the previously treated effluent by adding activated carbon (density $0.41 \mathrm{~g} / \mathrm{cm}^{3}$ with an area of 600$800 \mathrm{~m}^{2} / \mathrm{g}$ ), in concentrations of 0.5 to $0.8 \mathrm{gL}^{-1}$ to assess the adsorption potential. Based on the coagulant's best condition and activated carbon mass, the previously treated samples (coagulant + activated carbon) were subjected to a separation step with the ultrafiltration membrane (UF).

\subsection{Analytical determinations.}

Analytical determinations were performed with the effluent before and after the treatment procedures. The apparent color was measured according to the spectrophotometric method, using a colorimeter (Hach DR870), at a wavelength of $455 \mathrm{~nm}$. The results were expressed in "Hazen unit" or "uH", which corresponds to the color increase caused by the addition of $1 \mathrm{mg} . \mathrm{L}^{-1}$ of $\mathrm{Pt}$ as a chloroplatinate ion [28]. Turbidity was measured by the absorptiometric method by direct reading on a digital colorimeter (Hach, DR870), calibrated with standard formazine suspensions.

This study's standard method for Chemical Oxygen Demand (COD) was the microscale colorimetric method. Biochemical Oxygen Demand (BOD) was determined by dilution and incubation at $20^{\circ} \mathrm{C}$ for 5 days [29]. Both results were expressed in mg.L.-1. 
Total Organic Carbon (TOC) and Total Nitrogen $\left(\mathrm{N}_{\text {total }}\right)$ analyzer equipment (Shimadzu, TOC-5000A) was used. The sample was prepared from a $1 \mathrm{~mL}$ aliquot of the effluent, previously filtered through a membrane $(0.45 \mu \mathrm{m})$, and diluted to $25 \mathrm{ml}$ with distilled water. The determinations were carried out by catalytic oxidation at high temperature $\left(680{ }^{\circ} \mathrm{C}\right.$ for TOC and $720^{\circ} \mathrm{C}$ for $\mathrm{N}_{\text {total }}$ ). For TOC, the content was determined by the difference between total carbon and inorganic carbon concentrations. Results were expressed in mg. $\mathrm{L}^{-1}$.

The $\mathrm{pH}$ readings were carried out at room temperature $\left(25^{\circ} \mathrm{C}\right)$, in a digital bench $\mathrm{pH}$ meter ( $\mathrm{pH}$ LAB 827, Metrohm), previously calibrated with suitable standards.

The sedimentable solids' readings were carried out at room temperature $\left(25^{\circ} \mathrm{C}\right)$ in an Imhoff cone up to the volume of $1000 \mathrm{~mL}$, leaving the liquid to rest for 45 minutes. After the solid residues were deposited on the walls, they were gently moved with a glass rod towards the bottom of the cone and left for another 15 minutes to completely decant the solid material. Finally, the solid material was read in milliliters.

The analyzes of Total Phosphorus $\left(\mathrm{P}_{\text {total }}\right)$ were performed by the colorimetric method. For this, a concentrated solution of hydrochloric acid and sulfuric acid is added to an aliquot of the sample, followed by a solution of hydrochloric acid and ammonium molybdate diluted in distilled water and a small measure of ascorbic acid for staining the sample. The absorbance was determined at $660 \mathrm{~nm}$ in a spectrophotometer (Pro-Analysis, UV-1600, Brazil). Qualitative determination of sucrose was performed using Fehling's reagent [30].

\section{Results and Discussion}

\subsection{Characterization of raw effluent.}

The effluent from the washing machine for returnable glass bottles from the soft drink industry was characterized by COD, TOC, total phosphorus, total nitrogen, sedimentable solids, color, and turbidity (Table 1). From the results obtained, it was possible to observe that the raw effluent has low turbidity and low contents of total phosphorus and total nitrogen. However, it has high levels of COD, BOD, and TOC, parameters above those recommended for disposal, and even reuse in the unit by current legislation, [31] indicating the need for a treatment step before disposal.

Table 1. Results of the characterization of the raw effluent compared to the CONAMA standards.

\begin{tabular}{l|c|c} 
Parameters & Raw effluent & CONAMA \\
\hline Turbidity $(\mathrm{NTU})$ & 3.0 & $<40$ \\
\hline Color $(\mathrm{uH})$ & 4.0 & not visible \\
\hline Sedimentable Solids $\left(\mathrm{mL}_{\mathrm{L}} \mathrm{L}^{-1}\right)$ & 2.0 & not visible \\
\hline COD $\left(\mathrm{mg} . \mathrm{L}^{-1}\right)$ & $9,239.9$ & 400 \\
\hline BOD 5 days $\left(\mathrm{mg} . \mathrm{L}^{-1}\right)$ & $4,375.1$ & 120 \\
\hline TOC $\left(\mathrm{mg} . \mathrm{L}^{-1}\right)$ & $5,207.2$ & - \\
\hline $\mathrm{N}_{\text {total }}\left(\mathrm{mg} . \mathrm{L}^{-1}\right)$ & 5.6 & $<20.0$ \\
\hline P $_{\text {total }}\left(\mathrm{mg} . \mathrm{L}^{-1}\right)$ & $<0.1$ & $<5$ \\
\hline Sucrose $(\mathrm{Qualitative})$ & Positive & -
\end{tabular}

When performing preliminary tests using only the UF membrane, turbidity, color, and sedimentable solids were zeroed after the separation process. However, the COD and TOC parameters did not suffer reductions, presenting values similar to those of the raw effluent, indicating that the ultrafiltration membrane process applied directly to the raw effluent did not provide changes that would allow the proper disposal of this effluent according to the current 
legislation. Considering the characteristics of the soft drink industry's effluent, the results observed were due to the presence of sugars (sucrose), which is one of the main raw materials of this type of product, with a concentration of $6.74-12.82 \mathrm{mg} / 100 \mathrm{~mL}$ in the soft drink [32]. Its particle size, smaller than $1 \mathrm{kDa}$ (which was calculated considering that 1 sucrose molecule $(\mathrm{PM}=342.3 \mathrm{~g} / \mathrm{mol})$ corresponds to $5.68 \times 10^{-20} \mathrm{~g}$ and $1 \mathrm{kDa}$ is equal to $\left.1.66 \times 10^{-21} \mathrm{~g}\right)$, hinders its removal by UF membranes, which are characterized by having pore sizes equal to or greater than $50 \mathrm{kDa}$, justifying the inefficiency observed in the UF process.

In this context, previous chemical tests were proposed to assist in reducing COD and TOC, which can be applied alone or associated with other processes to obtain values that allow the disposal of the effluent or even its reuse in the industry.

\subsection{Aluminum sulfate.}

Aluminum sulfate (10\%) as a coagulating agent presented adequate coagulation for all conditions evaluated. However, the flakes formed showed different trends in the phase separation. It can be seen that the concentration that showed the best results (lowest values for COD and TOC), with a reduction of $5.42 \%$ for COD and $3.95 \%$ for TOC in the raw effluent, was carried out using $4.5 \mathrm{~mL} . \mathrm{L}^{-1}$ of aluminum sulfate (Table 2). Also, this concentration was the one that presented the best floc formation in the decantation as a separation step.

Table 2. COD and TOC results with different concentrations of aluminum sulfate.

\begin{tabular}{|c|c|c|c|c|}
\hline \multirow{2}{*}{$\begin{array}{l}\text { Concentration } \\
\left(\mathbf{m g . L} \mathbf{L}^{-1}\right)\end{array}$} & \multirow{2}{*}{$\begin{array}{c}\text { COD } \\
\left(\mathrm{mg} . L^{-1}\right)\end{array}$} & \multirow{2}{*}{$\begin{array}{c}\text { TOC } \\
\left(\mathrm{mg.L}^{-1}\right)\end{array}$} & \multicolumn{2}{|c|}{ Reduction in relation to the raw effluent $(\%)$} \\
\hline & & & COD & TOC \\
\hline 2.0 & $9,129.8$ & $5,198.2$ & 1.19 & 0.17 \\
\hline 2.5 & $9,101.3$ & $5,110.2$ & 1.50 & 1.86 \\
\hline 3.0 & $9,021.3$ & $5,049.2$ & 2.37 & 3.03 \\
\hline 3.5 & $8,923.5$ & $5,005.7$ & 3.42 & 3.87 \\
\hline 4.0 & $8,831.9$ & $5,003.7$ & 4.42 & 3.90 \\
\hline 4.5 & $8,739.2$ & $5,001.3$ & 5.42 & 3.95 \\
\hline 5.0 & $8,741.2$ & $5,007.8$ & 5.40 & 3.83 \\
\hline
\end{tabular}

However, it should be noted that the variation observed for COD and TOC fluctuated slightly between the concentrations of aluminum sulfate evaluated (maximum of 5.42 and $3.95 \%$ of reduction in relation to the raw effluent, respectively), indicating a tendency of stabilization of the results in the studied concentration range, that is, this flocculant is not the most indicated for this effluent.

\subsection{Ferric chloride.}

The COD and TOC values obtained for samples submitted to different concentrations of flocculant $\left(\mathrm{FeCl}_{3}\right)$ are shown in Table 3, which shows that the concentration that presented the best results (lowest values for COD and TOC), with a reduction of 5.5\% for COD and 3.8\% for TOC in the raw effluent, was carried out using a concentration of $45 \mathrm{mg} . \mathrm{L}^{-1}$. This result may be due to denser flakes' formation, which facilitates their separation from the liquid phase [33]. However, it increased the color and turbidity of the treated effluent, which was linked to the presence of $\mathrm{Fe}^{3+}$ ions in the solution. 
Table 3. Results of the characterization of the raw effluent compared to the CONAMA standards.

\begin{tabular}{|c|c|c|c|c|}
\hline \multirow{2}{*}{$\begin{array}{c}\text { Concentration } \\
\left(\mathbf{m g} \cdot \mathbf{L}^{-1}\right)\end{array}$} & \multirow{2}{*}{$\underset{\left(\mathrm{mg}^{\prime} \mathrm{L}^{-1}\right)}{\text { COD }}$} & \multirow{2}{*}{$\begin{array}{c}\text { TOC } \\
\left(\mathrm{mg.L}^{-1}\right)\end{array}$} & \multicolumn{2}{|c|}{ Reduction in relation to the raw effluent $(\%)$} \\
\hline & & & COD & TOC \\
\hline 10 & $9,145.6$ & $5,132.9$ & 1.02 & 1.4 \\
\hline 20 & $9,100.1$ & $5,102.1$ & 1.51 & 2.0 \\
\hline 30 & $8,987.2$ & $5,007.2$ & 2.73 & 3.8 \\
\hline 35 & $8,434.6$ & $4,879.2$ & 5.72 & 3.3 \\
\hline 40 & $8,897.5$ & $5,005.3$ & 3.71 & 3.9 \\
\hline 45 & $8,730.9$ & $5,009.3$ & 5.51 & 3.8 \\
\hline 50 & $8,723.6$ & $5,014.9$ & 5.59 & 3.7 \\
\hline
\end{tabular}

It should be noted that the variation observed for COD and TOC as well as fluctuated slightly between the concentrations evaluated, indicating that this flocculant is also not the most suitable for this effluent.

\subsection{TANFLOC.}

The results of COD and TOC for the effluent treated with different concentrations of TANFLOC are shown in Table 4. The concentration carried out using $60 \mathrm{mg} . \mathrm{L}^{-1}$ presented the lowest COD and TOC values, with a reduction of $53.5 \%$ for COD and $48.3 \%$ for the TOC in the raw effluent. This concentration of TANFLOC showed the best floc formation compared to the other tested flocculants.

Table 4. COD and TOC results with different concentrations of TANFLOC.

\begin{tabular}{|c|c|c|c|c|}
\hline \multirow{2}{*}{$\begin{array}{c}\text { Concentration } \\
\left(\mathrm{mg.L}^{-\mathbf{1}}\right)\end{array}$} & \multirow{2}{*}{$\begin{array}{c}\text { COD } \\
\left(\text { mg.L }^{-1}\right)\end{array}$} & \multirow{2}{*}{$\begin{array}{c}\text { TOC } \\
\left(\mathrm{mg.L}^{-1}\right)\end{array}$} & \multicolumn{2}{|c|}{ Reduction in relation to the raw effluent (\%) } \\
\hline & & & COD & TOC \\
\hline 30 & $7,349.7$ & $5,099.2$ & 20.5 & 2.1 \\
\hline 35 & $6,449.7$ & $5,002.2$ & 30.2 & 3.9 \\
\hline 40 & $6,049.7$ & $4,998.0$ & 34.5 & 4.0 \\
\hline 45 & $6,039.7$ & $4,059.3$ & 34.6 & 22.0 \\
\hline 50 & $5,749.7$ & $3,387.3$ & 37.8 & 34.9 \\
\hline 55 & $5,499.7$ & $3,278.9$ & 40.5 & 37.0 \\
\hline 60 & $4,299.7$ & $2,690.3$ & 53.5 & 48.3 \\
\hline 65 & $4,399.7$ & $2,600.4$ & 52.4 & 50.1 \\
\hline 70 & $4,349.7$ & $2,603.5$ & 52.9 & 50.0 \\
\hline 75 & $4,449.7$ & $2,805.6$ & 51.8 & 46.1 \\
\hline 80 & $4,549.7$ & $2,831.2$ & 50.8 & 45.6 \\
\hline
\end{tabular}

Studies that investigated the use of Tanfloc in the biofilm process's wastewater treatment process showed excellent results in removing undesirable solids, reducing chemical and biochemical oxygen demands, and providing water whitening [34]. Compared with conventional coagulants, such as aluminum sulfate and ferric chloride, TANFLOC was significantly more successful in terms of chemical oxygen removal, reducing it by up to approximately $90 \%$ [35]. Finally, the use of tannin-based coagulants and flocculants isolated or combined with other elements has been approached as an efficient alternative for highperformance wastewater treatments and a highly promising strategy for recovering this resource. Also, TANFLOC is a natural product, and its sludge can be added to the soil as an agricultural reconditioner.

The low removal observed in the coagulation process can also be related to sugars (polyalcohols). Due to their high polarity and solubility in water, they are characterized as difficult to remove molecules through coagulation. In this context, the best results observed for TANFLOC can be justified by its organic characteristic, which tends to present through intermolecular interactions (hydrogen bonds, dipole-dipole interactions) greater affinity for sugars, contributing to their aggregation and consequent removal, about aluminum sulfate and ferric chloride, with ionic characteristics. However, the COD and TOC reductions did not meet 
the parameters stipulated by current legislation [30], which indicates the need for the sequential application of another type of treatment.

\subsection{Adsorption with activated carbon.}

As a complementary step to chemical flocculation, adsorptive tests were carried out using different amounts of activated carbon (between 0.5 and $0.8 \mathrm{~g} . \mathrm{L}^{-1}$ ) in the effluent treated with TANFLOC (60 mg.L $\left.\mathrm{L}^{-1}\right)$. The percentage amount removed for both COD and TOC fluctuated numerically between $7.5 \pm 1.8$ and $4.3 \pm 1.5 \%$, respectively.

The similarity of the results for the different ranges using the mass of activated carbon suggests that the use of $0.5 \mathrm{~g} / \mathrm{L}$ is sufficient and desirable. Considering the current legislation, [30] the treated samples' COD values do not yet satisfy the current legislation, indicating the need to apply another type of treatment associated with those already tested. In this context, the samples treated chemically (coagulation) and adsorptively (activated carbon) were submitted to a new stage using the UF process.

\subsection{UF tests after flocculation and adsorption.}

The sample treated with TANFLOC and activated carbon was filtered through filter paper and subjected to the membrane test. The pressure was first set at 1 bar for the membrane test with a flux of $1 \mathrm{~L} \cdot \mathrm{min}^{-1}$. Fouling was also measured, and after the passage of the effluent, cleaning with commercial detergent was carried out. A new flux test was carried out to verify the effectiveness of this cleaning (Figure 1).
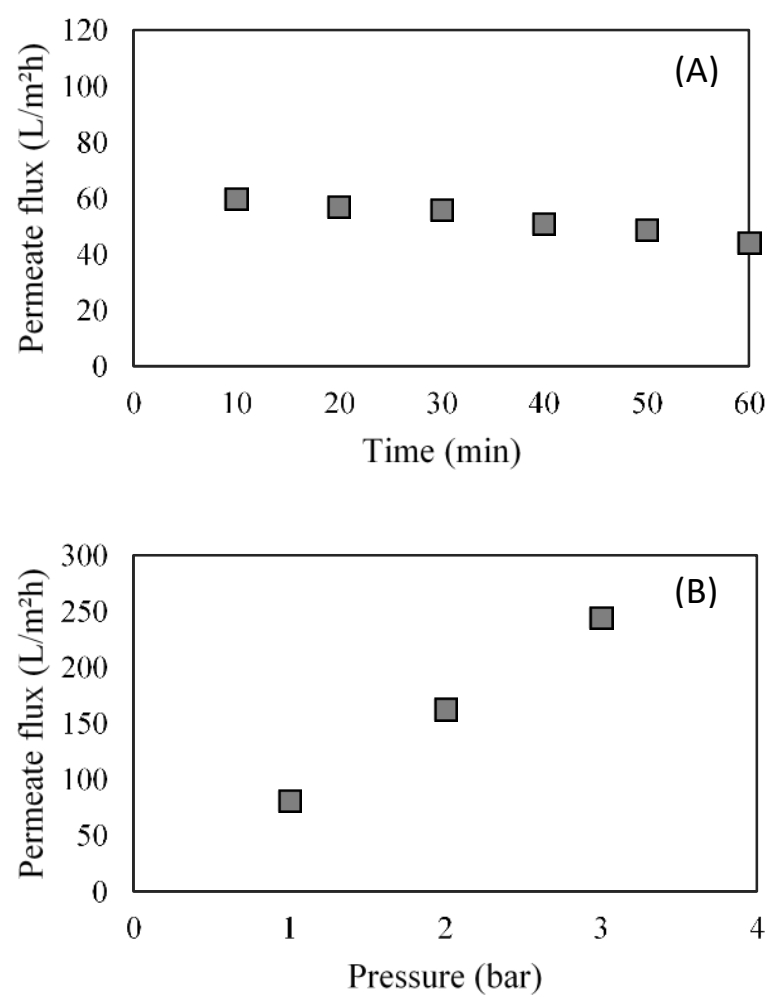

Figure 1. Permeate flux of (A) effluent treated with TANFLOC and activated carbon in the ultrafiltration membrane, and (B) after cleaning step.

TANFLOC presented $26 \%$ drop in flux, starting at $60 \mathrm{~L} . \mathrm{m}^{2} \mathrm{~h}^{-1}$ and ending at $44 \mathrm{~L} . \mathrm{m}^{2} \mathrm{~h}-$ ${ }^{1}$ (Figure 1A). The initial flux corresponds to approximately $40 \%$ of that observed initially for the membrane with distilled water. The lower starting flux and more accentuated fouling were 
linked to the organic characteristics and molecular weight of TANFLOC, which can increase the clogging of the membrane when depositing on its surface, preventing the passage of permeate. The proposed cleaning was also efficient to recover the initial flux of the membrane (Figure 1B).

For COD and TOC, removals were 63.64 and 54.92\%, respectively, 4.3 and $4.2 \%$ higher than those observed for TANFLOC + activated carbon (Figure 2). The values for the effluent's characterization before and after the associated treatment are shown in Table 5. For BOD, the value found was $1,680.0 \mathrm{mg} / \mathrm{L}$. Even though it is above $120 \mathrm{mg} / \mathrm{L}$, according to current legislation, as it has a removal efficiency of $64.98 \%$, that is, above $60 \%$, it could be discarded to this parameter.

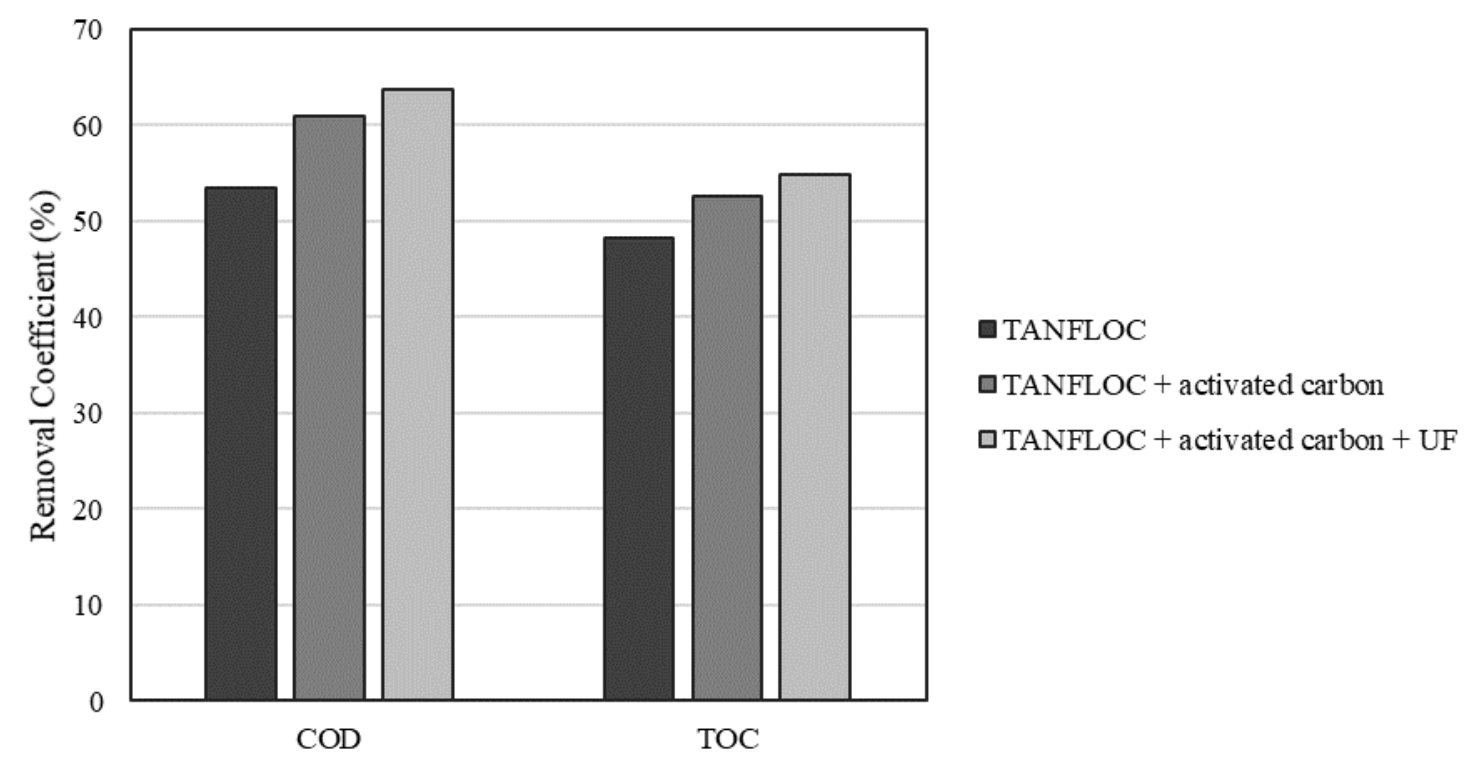

Figure 2. COD and TOC removal coefficient (\%) in the processes of coagulation, adsorption, and UF membrane.

Table 5. Characterization of the raw and treated effluent using the associated process TANFLOC, activated carbon and UF.

\begin{tabular}{l|c|c|c|c} 
Parameters & Raw effluent & Treated effluent & CONAMA & Reductions (\%) \\
\hline BOD 5days $\left(\mathrm{mg} . \mathrm{L}^{-1}\right)$ & $4,798.1$ & $1,680.0$ & 120 & 64.98 \\
\hline COD $\left(\mathrm{mg} . \mathrm{L}^{-1}\right)$ & $7,920.3$ & $2,879.2$ & 400 & 63.64 \\
\hline TOC $\left(\mathrm{mg} . \mathrm{L}^{-1}\right)$ & $5,207.0$ & $2,347.3$ & - & 54.92 \\
\hline Ptotal $\left(\mathrm{mg} . \mathrm{L}^{-1}\right)$ & $<0.1$ & $<0.1$ & $>20.0$ & \\
\hline $\mathrm{N}_{\text {total }}\left(\mathrm{mg} . \mathrm{L}^{-1}\right)$ & 5.6 & 4.2 & Up to 1 in 1 hour & \\
\hline $\begin{array}{l}\text { Sedimentable solids } \\
\left(\mathrm{mg} . \mathrm{L}^{-1}\right)\end{array}$ & 3 & 0 & Not visible & \\
\hline Color $(\mathrm{uH})$ & 3 & 0 & $<40$ & \\
\hline Turbidity (NTU) & 3 & 0 & - &
\end{tabular}

The small increase in the COD and TOC removal efficiency observed when using the UF membrane combined, as final polishing, would not justify its implementation costs. However, this small difference may be the differential to fit the effluent to the BOD parameter, whose removal efficiency was approximately 5\% higher than the minimum required by legislation for this parameter.

Despite a good removal in both COD and BOD (above 60\%), the values obtained in the treated effluent are higher than the emission limits required by the legislation. Due to their high polarity and solubility in aqueous media, sugars are characterized as difficult to remove compounds, being linked to the inefficiency of the process observed for BOD. 
Considering this study, it was widely discussed that the process for producing and obtaining soft drinks in industrial companies generates large amounts of wastewater. With the growing concern about the sustainable exploitation of resources, this scenario exposes the necessity for reusing water for other procedures incorporated in industries that require this element, such as processes for cleaning the location and techniques that do not require essentially pure water. Thus, effective treatment and low operating costs make wastewater recovery an important alternative for a highly promising and rapidly expanding sector.

The reuse of effluents produced industries is a highly economically and sustainably viable option, especially since some developed operational processes do not require highly pure water [35-36]. The necessity to use water for operational processes can be reduced if these processes are carried out under closed-circuit conditions, considerably reducing costs and using this element in several other procedures [37]. Industrial water treatment is also a critical topic since untreated wastewater can pollute water bodies and have many consequences for the environment [38]. In conclusion, costs involving waste treatment can be converted into environmental gains and contribute to the regional economy [39].

\section{Conclusions}

In conclusion, it can be verified that the applied processes provided important information, mainly to the coagulant agent for the treatment of the water in the washing machine of returnable soft drink bottles. Among the tested coagulants, TANFLOC showed the best results. Its treatment associated with activated carbon and UF membrane showed a $63.64 \%$ reduction in COD and $54.92 \%$ in TOC. BOD removal efficiency was approximately $5 \%$ higher than the minimum required by legislation. The direct application of the membrane over the raw effluent was not efficient since the COD, and TOC analyses' results did not significantly change. The results obtained represent a solution to water sustainability, allowing water consumption reduction through the partial or total reuse of the treated effluent.

\section{Funding}

This work was supported by the National Council for Scientific and Technological Development (CNPq) [grant number 308936/2017-5; 428180/2018-3]; Coordination for the Improvement of Higher Education Personnel (CAPES) [grant number 001]; and Research Support Foundation of the State of Rio Grande do Sul (FAPERGS) [grant number 16/25510000522-2].

\section{Acknowledgments}

This research has no acknowledgment.

\section{Conflicts of Interest}

The authors declare no conflict of interest.

\section{References}

1. Tahmassebi, J.F.; BaniHani, A. Impact of soft drinks to health and economy: a critical review. Eur. Arch. Paediatr. Dent. 2020, 21, 109-117, https://doi.org/10.1007/s40368-019-00458-0.

2. Yohannes, M.F.; Matsuda, T. Demand Analysis of Non-Alcoholic Beverages in Japan. J. Agric. Sci. 2015, 7, 143, https://doi.org/10.5539/jas.v7n5p143. 
3. Williams, S.N. The growth of the soft drinks industry in middle-income countries: current trends and policy implications in China and India. Perspectives in Public Health 2014, 134, 198-199, https://doi.org/10.1177/1757913914538142.

4. Demartini, M.; Pinna, C.; Aliakbarian, B.; Tonelli, F.; Terzi, S. Soft drink supply chain sustainability: A case based approach to identify and explain best practices and key performance indicators. Sustainability 2018, 10, 3540, https://doi.org/10.3390/su10103540.

5. Statista, Soft Drinks, Soft Drink. - Worldw. Available online: https://www.statista.com/outlook/20020000/100/soft-drinks/worldwide (accessed on 26 September 2020).

6. Cavalcante, L.M.; Machado, L.C.G.T.; Lima, A.M.M.d. Evaluation of the environmental performance and rationing of water consumption in industrial production of beverages. Revista Ambiente \& Água 2013, 8, 191202, https://doi.org/10.4136/ambi-agua.1212.

7. Scarborough, P.; Adhikari, V.; Harrington, R.A.; Elhussein, A.; Briggs, A.; Rayner, M.; Adams, J.; Cummins, S.; Penney, T.; White, M. Impact of the announcement and implementation of the UK Soft Drinks Industry Levy on sugar content, price, product size and number of available soft drinks in the UK, 2015-19: A controlled interrupted time series analysis. PLoS Med. 2020, 17, e1003025, https://doi.org/10.1371/journal.pmed.1003025.

8. Law, C.; Cornelsen, L.; Adams, J.; Pell, D.; Rutter, H.; White, M.; Smith, R. The impact of UK soft drinks industry levy on manufacturers' domestic turnover. Econ. Hum. Biol. 2020, 37, 100866, https://doi.org/10.1016/j.ehb.2020.100866.

9. Lacy-Nichols, J.; Scrinis, G.; Carey, R. The evolution of Coca-Cola Australia's soft drink reformulation strategy 2003-2017: A thematic analysis of corporate documents. Food Policy 2020, 90, 101793, https://doi.org/10.1016/j.foodpol.2019.101793.

10. Bandy, L.K.; Scarborough, P.; Harrington, R.A.; Rayner, M.; Jebb, S.A. Reductions in sugar sales from soft drinks in the UK from 2015 to 2018. BMC Med. 2020, 18, 20, https://doi.org/10.1186/s12916-019-1477-4.

11. Montaña Blasco, M.; Jiménez-Morales, M. Soft Drinks and Sugar-Sweetened Beverages Advertising in Spain: Correlation between Nutritional Values and Advertising Discursive Strategies. Int. J. Env. Res. Public Health 2020, 17, 2335, https://doi.org/10.3390/ijerph17072335.

12. Isla, M.A.; Comelli, R.N.; Seluy, L.G. Wastewater from the soft drinks industry as a source for bioethanol production. Bioresour. Technol. 2013, 136, 140-147, https://doi.org/10.1016/j.biortech.2013.02.089.

13. Remya, N.; Swain, A. Soft drink industry wastewater treatment in microwave photocatalytic system Exploration of removal efficiency and degradation mechanism. Sep. Purif. Technol. 2019, 210, 600-607, https://doi.org/10.1016/j.seppur.2018.08.051.

14. Victoria-Salinas, R.E.; Martínez-Miranda, V.; Linares-Hernández, I.; Vázquez-Mejía, G.; Castañeda-Juárez, M.; Almazán-Sánchez, P.T. Pre-treatment of soft drink wastewater with a calcium-modified zeolite to improve electrooxidation of organic matter. Journal of Environmental Science and Health, Part A 2019, 54, 617-627, https://doi.org/10.1080/10934529.2019.1579522.

15. Santos, C.E.D. dos; Rizk, M.C.; D’Avoglio, A.P.; Lima, L.C.N. Avaliação a alternativas de minimização do uso de água em uma indústria de refrigerantes. Revista de Gestão Social e Ambiental 2012, 5, 126, https://doi.org/10.24857/rgsa.v5i2.283.

16. Ait Hsine, E.; Benhammou, A.; Pons, M.N. Water Resources Management in Soft Drink Industry-Water Use and Wastewater Generation. Environ. Technol. 2005, 26, 1309-1316, https://doi.org/10.1080/09593332608618605.

17. Garg, M. Treatment and Recycling of Wastewater from Beverages/The Soft Drink Bottling Industry. In Advances in Biological Treatment of Industrial Waste Water and their Recycling for a Sustainable Future, Springer: 2019; 333-361.

18. Ben, J.; Mohamed, A.; Muduli, K. Optimizing Bottle Washer Performance in Cleaning Returnable Glass Bottles for Reuse in Beverage Packaging. Int. J. Adv. Sci. Technol. 2020, 29, 8149-8159.

19. Boguniewicz-Zabłocka, J.; Capodaglio, A.G.; Vogel, D. Analysis of Wastewater Treatment Efficiency in a Soft Drinks Industry. E3S Web Conf. 2017, 19, https://doi.org/10.1051/e3sconf/20171902014.

20. Farhaoui, M.; Hasnaoui, L.; Derraz, M. Optimization of drinking water treatment process by modeling the aluminum sulfate dose. Current Journal of Applied Science and Technology 2016, 1-14 https://doi.org/10.9734/bjast/2016/26840.

21. Li, X.; Liu, Y.; Liu, F.; Liu, A.; Feng, Q. Comparison of ferric chloride and aluminum sulfate on phosphorus removal and membrane fouling in MBR treating BAF effluent of municipal wastewater. Journal of Water Reuse and Desalination 2016, 7, 442-448, https://doi.org/10.2166/wrd.2016.151. 
22. Jiang, C.; Cui, S.; Han, Q.; Li, P.; Zhang, Q.; Song, J.; Li, M. Study on Application of Activated Carbon in Water Treatment. IOP Conference Series: Earth and Environmental Science 2019, 237, 022049, https://doi.org/10.1088/1755-1315/237/2/022049.

23. Rajasulochana, P.; Preethy, V. Comparison on efficiency of various techniques in treatment of waste and sewage water - A comprehensive review. Resource-Efficient Technologies 2016, 2, 175-184, https://doi.org/10.1016/j.reffit.2016.09.004.

24. Tonhato Junior, A.; Hasan, S.D.M.; Sebastien, N.Y. Optimization of Coagulation/Flocculation Treatment of Brewery Wastewater Employing Organic Flocculant Based of Vegetable Tannin. Water, Air, Soil Pollut. 2019, 230, 202, https://doi.org/10.1007/s11270-019-4251-5.

25. Obotey Ezugbe, E.; Rathilal, S. Membrane Technologies in Wastewater Treatment: A Review. Membranes 2020, 10, 89, https://doi.org/10.3390/membranes10050089.

26. Gonzalez-Perez, A.; Persson, K.M.; Lipnizki, F. Functional channel membranes for drinking water production. Water 2018, 10, 859, https://doi.org/10.3390/w10070859.

27. Basile, A.; Cassano, A.; Rastogi, N.K. Advances in membrane technologies for water treatment: materials, processes and applications; Elsevier: 2015; 551-580.

28. Federation, W.E.; American Public Health, A. Standard methods for the examination of water and wastewater. American Public Health Association (APHA): Washington, DC, USA 2005.

29. Lane, J.H.; Eynon, L. Determination of reducing sugars by Fehling's solution with methylene blue indicator; N. Rodger: 1934.

30. Conselho Nacional do Meio Ambiente - CONAMA, Resolução N 430, De 13 De Maio De 2011. Available online: http://www.mma.gov.br/port/conama/legiabre.cfm?codlegi=646 (accessed on 1 October 2020).

31. Godinho, M.d.S.; Pereira, R.O.; Ribeiro, K.d.O.; Schimidt, F.; Oliveira, A.E.d.; Oliveira, S.B.d. Classificação de refrigerantes através de análise de imagens e análise de componentes principais (PCA). Quim. Nova 2008, 31, 1485-1489, https://doi.org/10.1590/S0100-40422008000600039.

32. Ceni, G.; Dallago, R.M.; Mores, R.; Steffens, J.; Oro, C.E.D.; Denti, A.F.; Venquiaruto, L.D.; Tres, B.P. Avaliação da eficiência do cloreto férrico como coagulante no tratamento de um efluente sintético pelo método convenvional e eletrocoagulação. Vivências 2020, 16, 77-97, https://doi.org/10.31512/vivencias.v16i30.108.

33. Hameed, Y.T.; Idris, A.; Hussain, S.A.; Abdullah, N.; Man, H.C.; Suja, F. A tannin-based agent for coagulation and flocculation of municipal wastewater as a pretreatment for biofilm process. Journal of Cleaner Production 2018, 182, 198-205, https://doi.org/10.1016/j.jclepro.2018.02.044.

34. Campos, J.C.; Machado, B.d.S.; Blonski, M.E.D.; Bila, D.M.; Ferreira, J.A. Evaluation of coagulation/flocculation process in the landfill leachate treatment at the Municipal Wastewater Treatment Plant. Revista Ambiente \& Água 2013, 8, 43-53, https://doi.org/10.4136/1980-993X.

35. Redzwan, G.; Banks, C. An Evaluation of Soft-drink Wastewater Treatment by Anaerobic Digestion Process. Malaysian Journal of Science 2007, 26, 23-34.

36. Marchesi, C.M.; Paliga, M.; Oro, C.E.D.; Dallago, R.M.; Zin, G.; Di Luccio, M.; Oliveira, J.V.; Tres, M.V. Use of membranes for the treatment and reuse of water from the pre-cooling system of chicken carcasses. Environ. Technol. 2021, 42, 126-133, https://doi.org/10.1080/09593330.2019.1624834.

37. Abdel-Fatah, M.A.; Sherif, H.O.; Hawash, S.I. Design parameters for waste effluent treatment unit from beverages production. Ain Shams Engineering Journal 2017, 8, 305-310, https://doi.org/10.1016/j.asej.2016.04.008.

38. El Saidy, N.R.; El-Habashi, N.; Saied, M.M.; Abdel-Razek, M.A.S.; Mohamed, R.A.; Abozeid, A.M.; ElMidany, S.A.; Abouelenien, F.A. Wastewater remediation of heavy metals and pesticides using rice straw and/or zeolite as bioadsorbents and assessment of treated wastewater reuse in the culture of Nile tilapia (Oreochromis niloticus). Environ. Monit. Assess. 2020, 192, 779, https://doi.org/10.1007/s10661-020-08760$\mathrm{x}$.

39. Demaman Oro, C.E.; Bonato, M.; Oliveira, J.V.; Tres, M.V.; Mignoni, M.L.; Dallago, R.M. A new approach for salts removal from crude glycerin coming from industrial biodiesel production unit. Journal of Environmental Chemical Engineering 2019, 7, 102883, https://doi.org/10.1016/j.jece.2019.102883. 